WERETAYOSEPHWOUBALEM,

The Ethiopian Civil Service University,

Institute of Leadership and Good Governance (Addis Ababa, Ethiopia)

e-mail: Yoseph.Woubalem@ecsu.edu.et, ORCID 0000-0002-6727-5637

\title{
PEACE EDUCATION TO MANAGE INSTITUTIONAL CONFLICT AT ADDIS ABABA UNIVERSITY
}

The purpose of this research was to investigate conflict in Addis Ababa University (AAU) and thoroughly understand the conflict by identifying related factors: causes, nature and measures taken. Having explored all these factors the purpose extends to recommend peace education as a new intervention to resolve conflict in AAU. As a method of conflict prevention, the author offers the social technology Peace education, which means cultivating values, disseminating knowledge, developing relationships, skills and behavior aimed at achieving peace and harmony with oneself, with others and with the natural environment. The article provides practical advice and guidance on conflict management at universities.

Keywords: Conflict; Conflict Management; Peace Education; University; Addis Ababa; Ethiopia.

Introduction. Conflict is inevitable and natural. Its inevitability and natural phenomenon exists as long as human interaction exists in the world. Conflict is always active and thus unavoidable. Scholars have written abundantly about this reality. To mention (Watson, Watson \& Stanley, 2017: 1; Etim \& Okey 2013: 1) describe the prevalence of conflict as simply part of life and part of the world reality which is beyond human's capacity to avoid it.

This, being a reality in the world, the perception of conflict is another significant point to be discussed. It seems negative and unnecessary activity that disrupts work, environment, schooling activities and the like. It is observed as an activity that has no redeeming quality. Conflict that lacks positive outcomes and unable to add value are dysfunctional and destructive. Thus, there is also another reality that is prevalent which interprets differently conflict as a positive factor that adds value by bringing new insight, generating ideas and the like (Rahim, 2010: 32: Robbins \& Judge; 2013: 44 \& Posigha \& Oghuvwu, 2009: 15).

The contemporary approach and understanding has a different view. The view with logical arguments recognizes conflict not only as a reality but also as a positive factor in all organizations irrespective of their objectives and missions they accomplish. It argues that if conflict is not avoidable, the only alternative is managing it properly. If the management is proper and professional, it serves as an input for decision making, creates better ideas for problems, enhances work environment to be change oriented and not stagnant are among the benefits it brings about in a system (Okey \& Etim, 2013: 21; Khan \& Bibi, 2012: 21). Hence, conflict is a natural factor that also supports organizations if managed properly.

The scope of this study is to see the aforementioned realities in a university context, the conflict in Addis Ababa University(AAU). Hence, conflict in higher institutions cannot have a different reality. Higher education institutions cannot be considered as islands of intellectual properties where the complexities, conflicts and destruction outcomes of conflict are not frequently observed. As conflict is a universal phenomenon, it does affect universities. In this regard, Khan \& Bibi, (2012: 21) assert that universities are not enclaves and conflict is unobservable. The universities are well known for breeding conflicts. The reason for this is the structural arrangements in universities by nature make several functional boundaries created and the university community interacts with almost all of them in the course of teaching-learning process. Thus, students take many courses offered by different departments, and lectures in turn offer courses to different departments. Students raise their complaints and these complaints easily spread within the university community and reach to the university management without formal hierarchy. Moreover, revolts, protests and violence and due to these situations, constant closures of higher institutions can be common. Campus conflicts are growing from time to time in terms of their kind and levels of complexity. This is a vivid phenomenon that results from the change of societies and universities which are the products of these societies that are out rightly affected by external factors which create conflict (Etim \& Okey 2013: 17; Adeyemi \& Ademilu, 2012: 19).

The study site AAU, is the pioneer of higher education in Ethiopia which was established in 1950 as the University College of Addis Ababa. Since its establishment, it is recognized as an august higher education institution which is the leading higher learning and research institute. The university began its enrolment with only 33 students back in 1950 and currently, it has 48,760 students: 33,940 undergraduate, 13,000 graduate and $1733 \mathrm{PhD}$ students). The academic staff constitutes 2,408 academics and the 3,635 support staff). It has 14 campuses which accommodate its full enrollment. AAU is lead by a President and four Vice presidents and one Executive Director in different wings.

As conflict is an important feature of university life (Hamayaun, Muhammad, Khan \& Attia, 2014: 161). The study was interested to investigate this feature in AAU. It was delimited to the undergraduate program in the main campus because of two reasons. Firstly, the students come from all nine administrative regions belonging to different ethnic groups, cultures, religions, and geographical settings (rural and urban). Also, students have either no or limited exposure to integrate with other students who come from different backgrounds and conflict can take place 
between students and the university administration, between the students and the professors and sometimes between students and security forces. Secondly, there are more students in the main campus than the other campuses. These two reasons were considered as potential for conflict which can influence the university life in AAU. In line with this, it was better opportunity to make thick description in a qualitative study.

Ethiopia is a developing country which has 104 million people. The diversity in Ethiopia is described by more than 80 nationalities which most of them have their own languages and cultures as well. The diversity also involves different religions mainly, Orthodox Christians, Muslims, Protestants, Catholics and traditional beliefs. All these diversity boil down in AAU and it can be considered as a mini Ethiopia embracing all these diversities. Though diversity is one of the most ubiquitous features throughout all societies (Van Vuuren, Van Der Westhuizen \& Van der Walt, 2012: 12) in AAU it was observed as a big challenge and a source of conflict. The study focused in investigating the causes and understand the nature of conflict in the university.

As the study aims to investigate conflict, it also tried to propose peace education as a new solution. The recognition of conflicts and their causes demands a strong commitment (Muthanna \& Sang, 2017: 220) and should be followed by appropriate recommendation if the solutions are not satisfactory. The significance of universities for national development is undoubtedly understood, but the teaching learning process should be stable and such a situation can be created in crisis ridden free environment (Fatile \& Adejuwon, 2011: 19).

Hence, universities should be peaceful environment for achieving their grand mission of producing graduates who are also expected to have holistic personality, reputability and commitment to work for their nation. To sustain peace in a university, besides the formal policy framework, academics should also contribute its own share by introducing academic programs/courses based on research that indicates the need and its importance. In this regard, (UNESCO, 2013:1) defines the benefits of peace education as: "the process and practice of teaching and learning to pinpoint the challenges of achieving peace, developing non-violent skills and promoting peaceful attitudes. It is a central component of peace building." The study thus, formulated the research problem and posed main and sub research questions in order to propose peace education as a potential for peace building in AAU.

Statement of the Problem. Before 1991, even though the country was a home for diverse nations and nationalities, its unity was based on a highly centralized administration. This profile of the country was radically transformed to decentralized governance after the country officially endorsed a new constitution in 1994. The official recognition of diversity and decentralization became a radical transformation and the declaration of a federal state was in place. According to the ideology of this new constitution of Ethiopia in 1994, this scenario of decentralization asserts unity in diversity where diversity is considered as the basic indication of identity (FDRE, HPR: 2).

Hence, the new administration led by the Ethiopian People's Revolutionary Democratic Front (EPRDF) in its 1994 constitution decentralized all political, economic and social issues. In the education sector, the vernacular was used as a medium of instruction in regional states where students are more exposed and encouraged to local and regional matters. This is a popular merit to encourage and create students, who are shaped and dominated by regional and local values, attitudes, and experiences. However such students are also perplexed when they enroll in higher education institutions, because they find themselves in a diverse culture unknown to them. The huge campuses consisting tens of thousands of students from a heterogeneous society is strange for them. This is because most of the students come from rural settings where homogeneous ethnic group lived for years with a limited interaction and exposures with others.

In the past 10 years, conflict took place in some universities among students, between the students and the university administration, and between the security force and the students. This was what I, as a university Lecturer (though in another university) and a citizen of the nation who is concerned about young students who are the future of Ethiopia engaged in conflicts frequently observed in Addis Ababa University. Especially, the conflict amongst students was frequently observed every year which sometimes, though trivial instantly got aggravated and change to be a serious issue. Gradually, the sensitivity of the conflict took a position of an issue that was frequently discussed by government officials in several occasions and the international media especially the media that are concerned about the Ethiopian political, economic and social issues like the Voice of America and Deutsche Welle beyond the local media as well.

Though in Ethiopia there are new ethnic conflicts in several parts of the country one of the frequent and manifest conflict observed was in the universities including in AAU. Beside the above mentioned issues, as to my knowledge, few researches are conducted on conflict at the higher education institution in general and AAU in particular. It is against this scarcity of knowledge that I initiated this study and pose the research question:

How can peace education facilitate the management of institutional conflicts in the Addis Ababa University?

Aim of the Study. The aim of this study was to explore and explain conflict at a higher education institution, in order to propose peace education to manage conflict as a non-violent option of resolving conflicts. The specific objectives are: AAU;

to document the nature and cause of conflict in the

- to assess and explain the effectiveness of current efforts made to resolve conflict;

- to explore how peace education can be implemented resolve conflicts.

Significance of the Study. This section discusses the contribution of the research in terms of policy and scholarly activities are provided.

There is debate regarding peace education about its content and methodology. The debate is how to proceed with these essentialities uniformly. However, the solution is easy. The contents, methods and rationales have to be related to the differing contexts. The context is defined as the real situation i.e., and life the students who attend peace education. This as the internal environment, their context should also relate to the external environment which is outside the setting. Peace education thus, provides the privilege of "reading the world" to observe and direct, structural and cultural violence (Galtung, 2000) and through the internal lens with the relation of the external context. The result of such process leads to identifying the root causes in the internal context and the same in the external context to formulate visions of non-violent alternatives mainly peace building (Harris, 2004).

In relation to this, one significance of the result of the study is that it can influence the curriculum to be contex- 
tualized in the sense of Ethiopia. Thus, the curriculum is expected to bring about behavioral changes in terms of problem solving, critical thinking, self-awareness and empathy in dealing with personal/relational and/or cultural conflicts. The curriculum should also be able to enable resolving and transformation of conflict in personal relations and in multi cultural settings extending to see the international contexts (Yonas, 2018: 197). The study therefore can shape the attitude of students to see a bigger picture, not to see only their respective ethnicity, but rather to see themselves as citizens of a nation that has diverse nationalities if peace prevails fully who can contribute to the national development and tranquility and also active members of the Horn of Africa, a wider perspective.

Currently, the Ethiopian government has restructured the State Cabinet and introduced a new ministry which is the Ministry of Peace. This is a big leap for the commitment of sustainability of peace in the nation. This study therefore, can serve as an input to highlight the real experiences existing in AAU. The study also has greater probability to be generalized and bring about the experiences of other universities in Ethiopia. Hence, policy makers with special reference to the Ministry of Peace can use the study to establish new policies and/or review previous policies, manuals and practices.

Another significance is related with literature. The evolution of peace education takes its root to the Biblical teachings of Moses and Jesus Christ but formally recognized by the Americans in 1948. The practice of offering peace education is still continuing to date. In this evolution of peace education, there is a significant and observable dynamic shift from religious contents to conflict prevention mechanism (Chelule, 2014: 176-177). The dynamism of peace education requires to be 'elicitive' and 'transformative' rather than 'prescriptive' and 'directive' (Harris: 2004: 34). In other words it means creating better understanding the nuances such as the causes of conflict are paramount to update the intervention strategies in different contexts and targets (Harris, 2004; Omeje, 2015; Ramsbotham, Woodhouse, \& Miall, 2016). The dynamism in peace education is appreciable but it also indicates the dearth of literature which satisfies current and changing situations and practices. This research conducted in AAU has its own peculiar contexts, target group and other specific issues. Though peace education has a universal nature, the specific issue and discussions will substantially add to the literature in addition to opening more space for discussion and debate on conflict and peace education in higher education.

The need for research on peace education, I assume shall have a wider scale in the near future. As mentioned in this section, the country a Ministry of Peace and indicate the commitment of the country for the issue. The ministry is assumed to undertake various researches, programs and projects. Hence, the study can help in providing information for further researches. In line with this, academicians and researchers can use the research as a springboard for further research.

As discussed under section 2, figure1, Ethiopia is located in a fragile region and its peace situation is found to be low. However, this situation should be changed and improved and much more is required in through peace building activities. Hence, recognizing that there would be several solutions to sustain peace, peace education contributes its own share as an important ingredient in tackling the main and root causes of conflict (Datzberger 2017: 330). All in all, the study will play its own role in this regard.

The second change is the volatile situation in the horn of Africa where all members of the country are in a dire need for peace. This situation was in place when I proposed the study, and in 2017 the global peace index indicates that only 2 member countries of the Horn of African countries are labeled as medium while the others are low and very low. Ethiopia is labeled as "low" (see figure below).

Table 1. - The 2017 Global Peace Index of the Horn of Africa and Surrounding Countries

\begin{tabular}{|c|c|c|c|}
\hline Country & $\begin{array}{c}\text { Level of } \\
\text { peace }\end{array}$ & $\begin{array}{c}\text { Peace } \\
\text { Index }\end{array}$ & $\begin{array}{c}\text { Rank against } \\
\text { 163 countries in } \\
\text { the overall index }\end{array}$ \\
\hline Eritrea & Low & 2.505 & 135 \\
\hline Ethiopia & Low & 2.477 & 134 \\
\hline Kenya & Medium & 2.336 & 125 \\
\hline Somalia & Very Low & 3.387 & 158 \\
\hline South Sudan & Very Low & 3.524 & 160 \\
\hline Uganda & Medium & 2.182 & 105 \\
\hline
\end{tabular}

Source: the 2017 Global Peace Index in (Yonas; 2019: 190).

The higher the index, the lower the level of peace in a country

As indicated in table 1. above, the Horn of Africa in general, and Ethiopia in particular a lot has to be done to change this profile. Though education cannot be a sole solution to all problems, still it can contribute its own and with the support of other solutions can make change.

Thus, peace education is recognized as a transformative cosmopolitan approach and prevent violence rather entrench a culture of peace (Yonas, 2019: 187). Peace education further inculcates with skills of peace building in a certain context (Kester: 2010: 20), Galtung (2000) argues that avoiding physical violence which is negative peace to redressing structural and cultural violence through institutions and positive relationships to create positive peace. Hence, investigating the nature and causes of conflict and see to what extent employing peace education can transform conflict would be a better and a timely approach. Moreover, peace education is a multi disciplinary approach, and this study acknowledges the approach that emphasizes conflict resolution and I stress that peace education can serve as a potential to resolve conflict in AAU and create a better scenario both in the university, and as well in Ethiopia to create a better nationwide image. I then believe, that this study can bring about a new insight for managing conflicts through introducing peace education which makes the study timely and significant.

Methodology. The study used a qualitative approach and it is a case study focusing on Addis Ababa University. Thus, data were collected based on purposive sampling cognizant of the fact that adequate and reliable data would be collected. Hence, the university's leadership involving the Academic Vice President, the Business and Development Vice President, the Dean of Students, 10 department heads, and 70 students.

Semi-structured interviews were conducted with the University's officials and department heads and focus group discussions for the students which consist 7 groups each containing 10 members. The collected data were sorted and filtered and thematically analyzed.

Review of Related Literature

The concept of Peace and Peace Education

The concept of peace

There is no controversy about the essentialities of peace in this universe. Its prevalence is mandatory for human beings. Nothing positive can be obtained without 
peace. In this regard, Chinyere (2013: 346) explains that "peace is a value which is essential for the development of people and their environs". A society that built the elements of peace in its social structures is bound to be peaceful and secured. Peace is sometimes that is planned and prepared for. It cannot fall from heaven like manna, either can it be imported or extended to a country as grant or humanitarian materials The slogan that should dominate this century is if you want peace, prepare for it (Chinyere, 2013: 346).

But the basic definition of peace should be agreed upon. Various scholars and those concerned have defined peace in different forms. The concept of peace lends itself to several interpretations and definitions. Peace comes from Latin word, pax, which denotes contractual relationship implying recognition and agreement with human relationship (Chelule, 2014: 1). It is stated that ordinarily peace means the absence of conflict or violence at a particular time and place which evokes the climate of freedom from fear, intimidation and harassment, oppression and brutalization by external forces or agents (Nwafor, 2012: 1). In this regard, Ibeanu (2006) in Nwafor, (2012: 1) explains his observation that philosophers are not in agreement as to a universally acceptable view of peace. Rousseau's position that peace implies the original state of existence in which man was born as "a free gentle savage" - "a state of nature", is synonymous with a state of ignorance. For Hobbes, this "state of nature" was marred by frequent conflict and violence, which rendered life "solitary, poor, nasty, brutish and short". In order to avoid this ugly situation, human beings decided to surrender their rights to an overriding force, and thereby created a "social contract" for a more peaceful and orderly life. Plato, from the social context perspective, argues that justice is the fulcrum of ordered social life (Nwafor, 2012: 1).

In a contemporary perspective and simple way of defining it, peace, as a concept is primarily concerned with the creation and maintenance of a just order in a society. Miall (2004) in Sujatmiko (2012: 104) considers peace as the absence of war, respect and tolerance between people in the society. In other words, there should be harmony, tranquillity or wholeness in the organization of a system. In the sphere of institutional management, Galtung (2000) classifies peace into its negative and positive aspects. According to the study, when peace is said to be negative, it means that the peace in existence includes the absence of crisis, strikes, war, fear and direct violence in individual and at institutional levels. On the other hand, when peace is positive, it means that there is peace in existence, and it indicates absence of unjust structure, unequal relationship, justice and inner peace at the individual and societal levels.

Just as human nature is often portrayed as innately violent, peace is often portrayed as a tranquil, uncomplicated end state. This is a constricted and oversimplified view of peace. Peace is only partly the absence of war (negative peace) or a state of harmony and justice (positive peace). Fundamentally, peace is a long-term and gutsy project that seeks to bring about lasting and constructive change in institutions that maintain society (NOUN 2010: 20). Said differently, peace is "a dynamic social process in which justice, equity, and respect for basic human rights are maximized, and violence, both physical and structural, is minimized" Peace is not only the absence of war but also "harmony at all levels of human endeavor" (NOUN 2010: 20).

In a similar position, Salomon (2010: 142) argues that peace is much more than the absence of armed conflict.
Peace is the commitment to equality and justice; a democratic world free of physical, economic, cultural, political, religious, sexual and environmental violence and the constant threat of these forms of violence indeed against all of humanity.

Peace, in whatever form, level or environment it operates, is significant, in that, it is the greatest factor facilitating institutional management towards sustenance of performance. It is a pre requisite for any kind of organization. In a university context, peace means an environment where proper dialogue prevails, conflict is resolved through violent free solutions, a learning environment is created, and functional forms of conflict dominates the dysfunctional ones, internal means of resolution are introduced rather than a coercive means of resolutions are in place.

\section{Peace Education}

As peace is relatively defined in different contextualization, the notion and consumption of peace education has also various understandings. This part of the discussion tries to see these differences and as well create a platform for understanding peace education. Moreover, it deals with the purpose of peace education and attempts to show the middle or common ground of its purposes. It also provides the background and the evolution of peace education and some prominent scholars who exerted their efforts in introducing peace education and their contributions. This can provide a better insight of peace education in the contemporary world in general, and higher learning institutions in particular.

\section{Conceptualizing Peace Education}

Like the definition of peace, defining peace education is not uniform. Harris and Morrison (2013) contend that there is no universal definition of peace education. It is therefore a generic term that subsumes various kinds of education among them are nuclear age education, bomb education and disarmament education. Peace education, to other scholars, includes education for international understanding, political education, and global education. The purpose of education is generally for the promotion of development of consciousness of the world which enables people to work as global citizens and changing the current mode of thought and human condition and structures (Chelule, 2014: 2).

Understanding peace education after defining peace would be so significant because the why of peace education should clearly provide its rationale. The basic rationales for thinking about and launching peace education are associated with the increasing violent acts in general throughout the world and particularly also the recent prevalence of similar acts between students at schools in parallel with the social life. Hence, in recent years, "peace education" has started to attract the attention of researchers carrying out studies to prevent student violence at schools.

Generally speaking peace education may be perceived as a positive practice and notion. This may be because the phrase contains an entire positive element: peace and education. However, positive things by themselves may not be formalized and get implemented in any system because implementing a certain plan has its own cost implication and requires a whole management process from planning to monitoring and evaluation. Thus, it is highly preferable to be also formal and create some level of obligation by for instance making it supported by a certain policy or convention issued from a powerful and legal body. In this regard, peace education is acquainted and is recognized as part and parcel of an education system in universal bodies like the United Nations. One of 
the UN wings which deals with education UNICEF has dully recognized peace education as a significant approach for achieving specific targets. Accordingly, from the UNICEF perspective peace education is defined as follows.

"A process of promoting the knowledge, skills, attitudes, and values needed to bring about behaviour changes that will enable children, youth and adults to prevent conflict and violence, both overt and structural to resolve conflict peacefully and to create the conditions conducive to peace, whether at an intrapersonal, interpersonal, intergroup, national or international level".

The conceptual definition has strong rationale originating from different sources. One of it is the 1999 Convention on the Rights of the Child that enforces all member countries to abide to it supported by rationales. It states that the education delivered for the child should prepare children for "a responsible life in a free society in the spirit of understanding peace, tolerance, equality of sexes and friendship among all peoples". The convention declares that children should be well inculcated and cultivated towards the well being of the society that they will survive and work with in the future through a spirit of peace and tolerance along with other values. The peace education then is so paramount in creating such a generation in the globe. This rationale is a driving factor for formalizing and empowering peace education in the education system In addition to this, peace education is also mandated by The 1990 World Declaration on Education for All. The declaration generally states that every person in this world should benefit all opportunities from education. However, in the course of exploiting these opportunities and satisfying these needs individuals are empowered to shoulder responsibilities of being tolerant towards political and religious systems that differ from their own, and work for international peace and solidarity in an interdependent world.

This declaration is another rationale for peace education. The essential learning tools such as literacy, oral expression and numeracy and the basic learning content like knowledge, skills, values and attitudes contribute profoundly for the survival, development of capacity building and work with dignity, to actively participate in development and political issues and for the betterment of life and continual learning. All these require tolerance and peaceful actions. This implies that all acquisitions of knowledge and skills cannot be fully recognized as meeting the targets of education unless individuals react in a tolerable and peaceful manner in surviving and working in their respective societies and this is highly possible through peace education.

As the definition of peace is not uniform, so is the definition of peace education. It is controversial and its meaning is different for different people. The variation in meaning is viewed in a continuum where one extreme considers it as a political agenda and the other one perceives it differently (Wintersteiner, 2013: 15). Thus, peace education is found to be a difficult concept to accurately and comprehensively define. The subsequent emergence of peace education from time to time resulted in the various definition of the concept. The following definitions provide the differing perspectives of the issue.

\section{Peace Education and conflict resolution}

According to Albert and Albert (2011: 2) peace education is a conflict prevention method that describes the contribution of education to peace building. The term refers to all activities that promote the knowledge, skills and attitudes that will allow people of all ages, and at all levels, to develop the behaviour changes that can prevent the occurrence of conflict, resolve conflict peacefully, or create the social conditions conducive to peace. The goals of this kind of education are to construct a fair and democratic society; to discourage an always complaining hegemonic tendencies and youth militancy; and to seek cooperation, whether local or international, through learning from each other instead of sticking to compromises that ultimately do nobody any good. Peace education has to do with the promotion of cooperation between citizens and states, on a voluntary basis, in a variety of fields linked to education and culture, including human rights. It has to do with showing respect for cultural diversity, eliminating prejudice, and emphasizing positive mutual influence between different ethnic and religious groups (Ibid).

According to Harris (2003: 9) in Demir (2013: 1739) peace education aims to improve behaviours and knowledge necessary to form a secure world and a supportive environment. Main purpose of peace education is to grow the skill to think critically, analytically, and analogically. Interfering with children's cognitive, affective, and behavioural development during pre-school and school years is the only way to reduce conflict based solution tradition. This helps with the socialization of students (Auer 2002: 72 in Demir 2013: 1740).

The consideration of peace education for conflict resolution is a more viable means which escalates from behavioural change into a more tangible position. In this case, peace education serves as building a democratic society, tolerating cultural diversity and showing mutual respect for different culture, ethnic and religious groups.

\section{Overview of Conflict}

The history of human beings is not void of conflict and hence, conflict between human beings is as old as the history of mankind and it exists in all human relationships. Accordingly, Johns (1988 in Broni, 2012: 66), states that conflict is natural and in many ways inevitable because of the natural tendency in almost every human person to presume that their way of thinking and doing things is not only the best, but also the only right way. The matter becomes more routine especially in complex social structures like modern societies, where a vast number of people with different individual backgrounds, needs, and different goals live closely together. It is visible and pervasive in almost every day situations; at work, in school and at home and may come from any quarters.

Thus, there are no disagreements that conflict is an ever present phenomenon. However, unanimous definition of conflict is not available and it is defined in various forms by various scholars. According to Hellriegel and Slocum (2007) in (Koklu, 2012: 4) one of the important reasons for not having similar understanding is that conflicts occur in various situations and levels (between individuals, in groups, between groups, between personality, rules and norms) and in different intensity). Though the term conflict has no single or clearly defined understanding, the general agreement lies on those two things which are the basic elements of conflict: divergent views and the incompatibility of those views (Majola 2013: 15).

\section{Inevitability of conflict}

The old history of conflict with human beings is well understood by the contemporary world. Conflict is then recognized as an inevitable and natural situation. Its inevitability is not questionable. According to Oladitan Ajibua, Fashogbon and Ajayi (2014: 39) conflict is an inevitable and natural part of human existence and a permanent phenomenon in any organization, Likewise, most educational institutions also witnessed conflict as a result of its being inherent in human nature whenever goals 
and aspirations differ. The inevitability of conflict has its own roots. Conflict is inevitable in any organization because individuals entail differences in their opinions, beliefs and priorities. The inevitability of conflict in organizations is so visible because organizational managers are obliged to take conflict resolution as one of their core duties. Organizational leaders thus, require an advanced skill of conflict management and resolution because resolving conflict is mandatory. Williams (2011: 47) states that in large as well as small organizations, conflict between organizational members is usually frequent and certainly inevitable at some time or another. Managers have reported that they spend $20 \%$ of time dealing with some form of interpersonal conflict. These elements are ingredients of one's perception which is also a significant factor for conflict. Thus, the issue of inevitability is not a problem, but rather how to handle it (Mayer, 2012: 3). One of the reasons for its inevitability is the varied perception of people in organizations and thus, conflict is also viewed as a difference in perception.

\section{Nature of Conflict}

Even though there is no consensus on the definition of conflict, there are two opposite perspectives. Social views on conflict have shifted over time. There were traditional and conservative arguments which assert that conflict is entirely harmful while contemporary arguments are prevalent considering conflict as a positive vehicle for progressive change.

The early approach to conflict assumed all conflict was harmful and to avoided. Conflict was viewed negatively and discussed with negative connotations such as violence, destruction and irrationality. It used to magnify all dysfunctional outcomes that result from poor communication, lack of openness and trust between individuals in addition to the failure of managers responsibility to the needs and aspirations of their members within the organization (Robbins and Judge, 2014: 241). On the other hand, a contemporary approach to conflict argues that all conflicts are not bad. Those that are supportive for the goal of a group or organization are functional conflicts and the conflicts that hinder the performance of a group or organization are dysfunctional conflicts (Robbins and Judge, 2014: 241).

The consensus regarding the inevitability of conflict has resulted these two transitions of thought and hence, the implications of conflict has both functional and dysfunctional effects on organizational life depending on how it is managed. Effective management of organizational conflict is suggested to depend on the quality of organizational leadership behaviour (Odetunde 2013: 1). Even though many people view conflict as an activity that is almost totally negative and has no redeeming qualities; still some consider it as dysfunctional, destructive, and as the same time as a catalyst for change, creativity and production (Posigha \& Oghuvwu, 2009 in Ekim \& Okey, 2013: 2).

In this connection Adomi and Sylvester (2006) in (DiManna, 2012: 27) believe that even though conflict has a negative side, it still has a role to play in helping organizations to maintain viability and increase the chances for survival. Moreover, Anstey (2013: 17) states that despite that conflict has negative consequences because the attacking and destruction of involved parties are observed, it is not deniable that it is also a process for healthy group and inter group relations. The violence, misperceptions, stereotypes and social crises, can be good inputs for creativity, as long as it is handled properly. Simultaneously, it is also an energizer and a capacity for problem solving, and unification of groups to give them identity and meaning and as well create bonds with other groupings.

Even though conflicts are often perceived as negative, and as such must be addressed at all costs, there is evidence that conflict is not necessarily, or always negative. Conflict can be productive and in fact become a necessary part of positive interpersonal relationship, creating problem-solving and group cohesiveness to enhance leadership and other positive aspects in organizations. In spite of the many negative connotations of conflict (Broni, 2007 and Tjosvold, 1997 in Broni 2012: 67), argue that conflict is necessary for authentic involvement, empowerment and democracy. They also believe that conflict can be used to balance power, to improve communication, and to develop a foundation to manage differences. What makes conflict potentially dangerous is the fact that since a large number of people are unaware of how to identify it or deal with it when it initially occurs, it tends to be more recognizable mostly when its effects have escalated into destructive, sometimes irreparable levels.

Further discussions are forwarded from other authorities also. Even though conflicts are often perceived as negative, and as such must be eradicated at all costs, there is evidence that conflict is not necessarily, or always negative (Broni, 2007; Fillipo and De Waals, 2000 in Broni, 2012: 2); conflict can be productive and in fact become a necessary part of positive interpersonal relationship, creating problem-solving and group cohesiveness to enhance leadership (Wilson, 2007 in Broni, 2012: 2).

\section{Causes of Conflict}

The realization of conflict is a primary task in understanding conflict. A deeper understanding of conflict helps in managing and resolving it. A more systematic way of approaching it is therefore, a compulsory action while studying it. Hence, identifying the types and sources could help much for a deeper investigation. Conflict may have different types and originates from a number of sources, such as tasks, values, goals, and so on. It is of paramount importance to identify the types and sources of conflict for proper understanding of its nature and implications.

As conflict is understood from different perspectives, there would be so many causes of conflict. The complexity and nature of conflict leads to various classifications of causes. These multiple sources can fall under the different theories of conflict and get recognized and resolved accordingly. Locating and understanding these conflicts help to create a map to guide the conflict process. It further provides understanding the different forces that motivate conflict behaviour and handle the conflict effectively. This part discusses the possible causes of conflict.

Conflicts are caused by a number of aspects that create tensions between people. Corvette (2007) in Msila (2012: 25) contends that conflict exists wherever, and whenever there is an incompatibility of cognitions or emotions within individuals or between individuals. Many educational intuitions have broken down relationships because of the existence of this incompatibility (Msila, 2012: 25).

Several factors account for the root of conflict in any given community, the higher education being no exception. While the choice of the leadership of a community can be the source of conflict, religious, tribal or ethnic differences are also some major causes of conflict in almost any heterogeneous community. In some cases, generation or age differences, either in birth or membership of the institution can be a source of conflict. It has also been discovered that the struggle for power and the competition 
for the available scarce resources could serve as grounds for conflict (Botchwey, 2006; Broni, 2007 in Broni, 2012: 3).

Moreover, conflict is seen as arising from basic human instincts, from competition for resources and power, from the structure of the societies and institutions people create, from flawed communication, and from the inevitable struggle between classes. If conflict is understood and located, the sources of conflict help to create a map to guide through the conflict process (Mayer, 2012: 10). According to Moore, (2003) in (Mayer 2012: 10) the sources identified are relationship problems, data problems, value differences, structural problems, and interests. However, Mayer, (2012: 10) reflects a broader view of human needs and associated issues that are described in a wheel form.

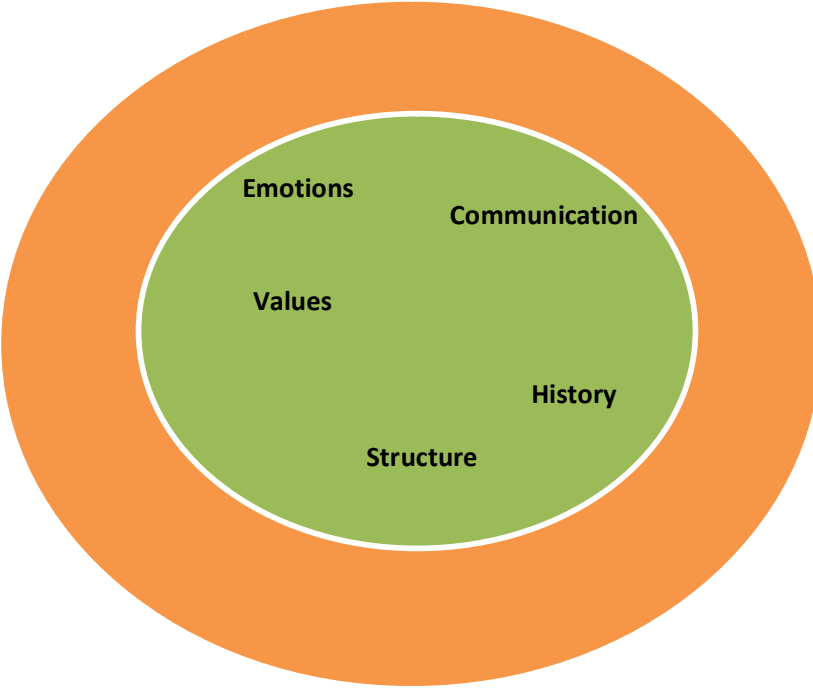

Mayer (2012: 10) discusses that it is possible to develop a usable framework for understanding the sources of conflict, we can create a map of conflict that can guide us through the conflict process. With regard to this research, Mayer also advises that conflicts arise from basic human instincts and the inevitable struggle between classes and that most conflict centres on human needs. This involves either unmet needs, or the belief that their needs are not consistent with others' needs. As a result, these needs cannot be ignored, but rather be addressed in order to avert conflict. Mayer uses what he has termed. The wheel of conflict (an analytical tool) which contains five significant conflict areas, namely: the way communication happens, people's emotions, values, and history, as well as the structures within which interaction happens is discussed here under.

The communication factor is an active source of conflict because our communication is imperfect which possibly could generate conflict. The other source of conflict is the emotions of people. The constraints take place because people are not always rational which would have made conflict de-escalated or managed properly. The value factor, perhaps a serious source of conflict is more charged and intractable and hard to compromise because conflicting parties feel that it is unable to compromise the sense of integrity and self.

The other source of conflict indicated is structure which includes like available resources, decision making procedures, time constraints, legal requirements, communication mechanisms and physical settings. These components may promote to a conflict even if they move towards a cooperative stance. The history of conflict on the other hand, though it is not a determinant factor of conflict is another cause of conflict. It is impossible to understand conflict independently from its historical context because history has a powerful influence on the course of the conflict itself. To sum up, the different sources of conflict interact with each other and while investigating the root causes of conflict it is possible to see all these causes.

\section{Summary of Findings}

\section{Conflict in Addis-Ababa University}

\section{Academic Reasons}

The operational and strategic functions of educational institutions are measured in student assessment along with the other factors. One of the basic elements in assessment is grading students. Grading is a sensitive part of assessment which indicates the level of achievement of students, being an indicator of whether students have succeeded or not. Among students, competing for success is a basic feature of life in the university. The students' grades are eagerly expected by the learners which develops interest and motivation. Unexpected grades, especially due to the error of instructors, create conflict between the students and the instructors.

Hence, assessment is crucial for the meaningful survival of educational institutions Vaessen, Beemt, Van Den, Watering, Van De, Ludo, Meeuwen, Lemmens, \& Brok, Den (2017: 872). Literature indicates that proper assessment of students is paramount in education. According to Brink and Lautenbach (2011: 503), properly assessing student performance is a basic issue in education and involves an ongoing evaluation process in tertiary education. It creates understanding of students' learning by rationally showing the measurement of the learning outcomes in terms of the learning domains. This is aimed at improving student performance. In relation to this important issue, Alquraan (2012: 125) stresses that fair and well-developed assessment methods have a positive impact on students. The assessment issue, though comprehensive and requiring technical competence, includes a variety of methods to determine the students' achievement (Aranda \& Yatews, 2009: 2).

Conflict in AAU is an ongoing phenomenon. However, the authorities generally attempt to control the conflict instead of managing, resolving and even treating the symptoms or transforming conflicts. Hence, they focus on treating the symptoms rather than investigating the root causes of conflict and reacting accordingly. There are multiple causes.

Conflict takes place between students and lecturers and professors due to students' assessment results. As grading is a sensitive issue in university students' life, conflicts are observed due to poor handling of the grading system. Students' future opportunities for employment and their perception for success satisfaction mainly depends on this issue. The absence of feedback and transparency is an academic gap that creates conflict. Students may not be informed of grades after they are approved by AAU officials, and often causes conflict. Moreover, grading students is a sensitive activity which requires commitment and serious attention. When unmet, these expectations can cause grievances and sometimes lead to conflict. The study revealed that the negligence of some lecturers to produce a reliable and justifiable grading provokes conflict. Grading as a pivotal issue because it cannot be free from interest and when interest does not match between two parties, conflict occur. However, it is not only grading that instigates conflict but also unsatisfactory instructional skill and poor classroom management that is found to be the source of conflict in AAU. 
The other reason of conflict in AAU is a very common cause in conflict management. Among the common causes of conflict perception is worth mentioning.

\section{Perception}

Perception is a process by which individuals organize and interpret their sensory impressions in order to give meaning to their environment (Robbins \& Judge, 2014: 165). However, what we perceive can be substantially different from objective reality. For example, all employees in a firm may view it as a great place to work favourable working conditions, interesting job assignments, good pay, excellent benefits, understanding and responsible management - but, as most of us know, it is very unusual to find such agreement. Why is perception important in the study of Organizational Behaviour. Simply because people's behaviour is based on their perception of what reality is, not on reality itself (Robbins \& Judge, 2014: 165). Conflict is an inevitable part of any organization and manifests between people in various contexts, including in higher educational institutions.

In this regard, students' perceptions often initiate conflict. The bias that is formed due to perception manipulates individuals (students) to form an opinion and attach meaning to a certain issue. Actions arise out of perceptions. The conflicts in AAU are observed to be caused by the perceptions students formulate of each other. Perceptions are subjective and can be positive or negative in different instances. Negative perceptions develop hostility and lead to conflict as revealed in the study. Students who live together on the same campus and learn several courses for years in the same university have weak social relationships due to the negative perceptions they develop. The study shows that students form negative perceptions of a certain ethnic group and their actions are dictated by their stereotyping. Moreover, they experience the same thing with religious affiliations.

\section{Ethnicity}

The study aimed at providing a comprehensive picture of AAU in terms of conflict and briefly investigated the past trends. The trends of AAU conflict were directly associated with the different political, social and economic demands of the mass of Ethiopia. Serious political struggles were dominated by Marxist ideology and raised the core issues of 'land to the tiller' and the right of nations to selfdetermination. Since these issues were first raised in AAU, there have been three changes in governments.

This trend remains evident in AAU communities, especially among students who still dwell on political, social and economic issues. Thus, whenever political decisions or policies are implemented, and when students claim that it they are not appropriate, they raise questions which creates conflict with the university administration and with the government administration /security forces.

Following the change of government in 1991, the question of the rights of nations and nationalities was addressed by the government, through an ethnicallybased form of federalism. This state structure initiated a new education and training policy that focused on teaching students in the vernacular since this had been one of the demands. However, the findings revealed that the various demands of the community were not addressed which caused frustration. Consequently, political dissatisfaction gradually grew and the usual opposition continued to be heard from the students' side: this situation caused conflict.

Hence, as indicated in the study, the main cause of conflict is ethnicity. From the past trends of AAU, students are sensitive to government policy. Likewise, the current students who were indoctrinated by ethnic federalism in their early ages in primary school take the issue seriously. Polarization and stereotyping are the most observable causes of ethnic conflicts. When students join universities coming from different regions of the country, they find themselves in diversity. Though diversity has its own benefits which are classified as individual benefits, institutional benefits and societal benefits, the challenges of diversity can bring about increased ethnocentrism, and negative relationships described by unfriendliness and hostility, rejection, divisiveness, scapegoating, bullying, stereotyping, prejudice and racism. Its negative impact it can affect the university community as well as the broader society outside the university (Abebaw, 2014: 2-3). In the Ethiopian context, as there are more than 80 ethnic nationalities (CSA, 2008), there is ethnic diversity. However, there is a strong and cogent argument against the FDRE Constitution which claims that ethnic federalism has strained the social fabric that once united people who belong to various ethnic backgrounds (Alagaw, 2012: 97).

When compared to conflicts caused by religious differences, the ethnic issue is found to be frequent and more serious. Students are found to have a myopic understanding of ethnicity and seem unable to tolerate others who do not belong to their ethnic group. In this connection, Ethnic-related issues are promoted by groups. Group thinking does not allow for much tolerance for others. Accordingly, Tilahun, (2007 as cited in Abera, 2010: 23) describes group positions as follows: "One major cause of the tensions that are maintained between various groups is the astounding degree of ignorance that they harbour about each other. Group tensions are based on prejudice ... equally, stereotypes also have a role to play in exacerbating groups' tension".

The ethnic issue, according to the findings of the study, is not only a source of conflict among students. It also involves confrontation with the government administration. Students raise the issue of unfair treatment of their respective ethnic groups by others, and they claim that some ethnic groups are favoured over others. Issues are complicated and take on a more serious tone when students start voicing their complaints, for instance, that their respective ethnic community is suffering from drought but nothing is being done about it. Above all, a huge conflict that took place during this study was the Oromo students' protest which was not confined to AAU but spread across the whole country. As the Oromo ethnic group is the largest population group in Ethiopia, its landscape is vast and crosses many of the other regions. The situation that complicated this protest and made the conflict serious was the new Addis Ababa Master Plan which integrates neighboring towns on the outskirts of Addis Ababa but are located in Oromiya Region (Addis Ababa itself is in Oromiya Region, but has its own autonomy and mandates enshrined in the FRDE Constitution). This was an ethnopolitical case which could not be resolved by the AAU alone but needed the intervention of the federal government. It finally led to significant reform, including the resignation of the Prime Minister, the release of thousands of political prisoners and the closure of a notorious detainee center.

\section{The Types of Conflict}

As one of the research questions and specific objectives of the research focus on understanding the types of conflicts and determine the nature of the conflicts, the study examined what types of conflicts have frequently taken place in AAU. In this connection, theoretically conflict can be classified as functional or dysfunctional, depending on the quality of conflict management. Well-managed conflicts are functional and poorly managed ones are dysfunctional. 
The conflict that took place in AAU as indicated briefly under originated either from external environmental influences or from internal grievances. Thus, conflict in $A A U$, was, by and large found to be dysfunctional or destructive. The study showed that conflicts in AAU developed hostility, rather than dialogue, negative effects than positive ones.

\section{Effects of Conflict}

Conflict is inevitable in all institutions despite what they wish to accomplish. Universities and academia are not exempted. Thus, their complex nature and the structure that fosters their mission generate conflict (Addo \& Koi, 2015: 53). There is a longstanding assumption that conflict is both functional (constructive) and dysfunctional (destructive) based on the differing and evolving traditional, human relations and interactionist views (Turkaij et al., 2015: 507). However, proper management of conflict is paramount.

Conflict thus has positive or negative effects. Properly managed conflict has a positive effect. The research investigation attempted to find out the outcomes of conflict and explored how they affected social relationships and the teaching-learning process. The findings are summarized briefly below.

In Ethiopian society like other African countries, social relationships are a highly respected social value that serves as a guide for life. Some skills such as social skills are paramount. However, when conflict interferes in social relationship, it would be in jeopardy. Findings thus indicate that conflict endangers social relationships in AAU.

\section{Conflict vs social relationships}

As briefly discussed, social relationships affected by conflict. The study provides abundant data in this regard. Hence, conflict caused by ethnic issues that involve the narrow stereotyping of others was observed to affect the relationships among students. The nature of such conflict is destructive and cannot have a positive outcome. The findings indicate that social relationships had deteriorated to the extent that some students did not even sit together. To make things more worse, students from different ethnic groups do not talk to one another, and when group assignments are expected to be delivered, their motivation to come together and attempt these assignments which are a course requirement, is found to be extremely low. Hence, the spirit of sisterhood and brotherhood is totally eroded. Underestimating of one ethnic group by another is commonly found among students. Due to this, some petty issues which could be resolved between individual students tend to change into ethnic issues thereby aggravating it. Some social relationships especially among Amhara, Oromo and Tigray ethnic groups seem to be worse than others. The issue of tolerance and awareness and accepting diversity is very low. In a study on ethnic identity and relations of Amhara, Oromo and Tigray students at Addis Ababa University main campus conducted by Abera (2010: 53), it is similarly discussed that the relationship among students is determined on the basis of ethnic affiliation or political alignment. This leads to a stereotyped and pessimist labelling. Therefore, students are reluctant and suspicious to interact with each other and tend to relate only to one homogeneous ethnic group. Hence, neither the aftermath of conflict nor potential conditions to create conflict bring about harmonious social relationships.

A study conducted by Bitwoded (2014: 139) states that the Ethiopian ethnic federal system affects the interaction of students and students are trapped in the web of ethnocentrism while engaging in social relations. The author further posits that due to the ethnic federalism, students are alienated from other ethnic groups. To sum up, social relationships deteriorate as the main cause of the conflict is ethnically based.

\section{Conflict vs teaching learning process}

University life mainly is characterised by the teachinglearning process. If a university community is in a state of dysfunctional conflict, this process is significantly affected. The interruption of classes is inevitable when serious conflicts occur because students do not feel comfortable in such situations. Students also divert their attention from their studies and may not be able to pursue their studies successfully. Besides this, university property and materials are also damaged.

\section{Conflict Resolution Mechanisms}

There are many conflict resolution mechanisms. Some mechanisms have a negative impact. Some have a winwin outcome where the parties compromise and others are entirely based on autocratic decisions. The leadership of an institution is estimated to use up to $20 \%$ of their time in resolving conflict, according to Mayer (2014: 53). In universities, the problem is more complex than in other organisations (Hamayun, 2016: 90). The vast majority of the university community, the various activities which require higher cognitive ability, the competitive merit system and the many individuals with high self-esteem makes the university scenario complicated and conflict-sensitive. Cognizant of this fact, the prevalence of conflict also demands appropriate conflict resolution strategies which would otherwise result in negative outcomes such as demotivation, reduced efficiency and lack of trust (ibid.). The following discussion briefly summarises the findings in this regard.

AAU exerts its effort to seek solutions for conflicts created in different times. These mechanisms have different approaches. The study revealed that efforts carried out by AAU involve mediation, negotiation and discussion between the conflicting parties. Giving advice and showing the right direction may be other interventions. More importantly, a Peace Club that hosts panel discussions is an interesting phenomenon found to exist in AAU. The Peace Club involves the university management and the board of directors. All these approaches have positive outcomes and show that it is possible for the needs of both sides to be met.

Forceful measures are taken which include, intervention of police force to the university campus and students are beaten and arrested. The federal police force which is accountable to the Federal Government fully controls all mobilization in AAU to hamper the conflict and this force has the power to put students to jail. Moreover, AAU takes administrative measures like suspending and dismissing students from the teaching learning process which will focus on individual students who are suspected to lead the conflict and the violence that followed.

\section{Effectiveness of conflict resolution}

Conflict resolution is the responsibility of leaders in any institution as discussed in the literature review as they are expected to spend about $20 \%$ of their time in conflict resolution functions. Evaluating the effectiveness of conflict management involves assessing its effectiveness and efficiency, implementing useful ideas extracted from functional conflict, and creating a peaceful working environment.

Effective conflict resolution mechanisms

Conflict resolution mechanisms may be either effective and ineffective. Effective resolution mechanisms those that result in the conflict coming to an end, according to the 
study findings. Mutual consent is initiated to create harmony and integration. The peace club is effective in diluting conflict and changing the tense environment. However, according to the discussion, some students agreed that formal and autocratic measures like dismissal of students and taking any appropriate formal measure that creates a stable situation were also regarded as effective, while others denounced such measures. AAU should take action which is formal and strict but in using such a conflict resolution mechanism, students should always be safe.

\section{Ineffective conflict resolution mechanisms}

Contrary to the discussion highlighted above in section conflict resolution mechanisms may be ineffective for various reasons, as per the study findings. Basically, using formal procedures and calling in external forces like the police to resolve conflict are found to escalate the conflict and do not give room for examining the root causes of the conflict and seeking radical solutions. Such processes overlook the potential underlying issues that could cause the conflict to flare up again. The formal binding legislation of AAU is not fully communicated to students and they do not know what measures would be taken for certain offences, as conflict is not traditionally encouraged and is considered as offensive. Thus, according to the findings, punishment and other forceful measures, including the intervention of the police, are ineffective because do not approach the resolution of conflict systematically by diagnosing the causes of conflict.

The aim of this study was to examine how peace education can serve as an initiative to resolve conflict in AAU. Thus, the data collected provided rich information concerning peace education.

The framework of peace education and its co-disciplines indicates that the significance of peace education is manifold. It can be used in different types of education such as development education, human rights education, disarmament education, environment education and the concern of the study i.e., conflict resolution.

Hence, data collected confirmed the significance and benefit of peace education since peace is recognized as a priority and a prerequisite in the teaching-learning process. Moreover, the significance extends beyond the university community, to the community as a whole and potentially to the whole nation. It is also considered as a strategic solution to be taken by AAU. Overall, from the nation's general situation point of view, peace education can contribute to the resolution of conflicts observed here and there in different times.

\section{Conclusions}

The aim of the research was to investigate how peace education can facilitate the management of institutional conflicts in AAU. The research posed three questions in attempting to seek answers to the research problem on the causes of the conflict in AAU.

Main Conclusion 1. The causes of conflict have been identified as, poor classroom management like negligence of teachers, perceptions and ethnic issues. Regarding perceptions, students develop wrong perceptions of others especially on the basis of ethnicity. This leads to conflict and polarization among them. Stereotyping dominates the students' perceptions. It is a habit built up over many years and is an enduring belief. Such thinking easily influences attitude and action, leading to the destruction of social relationships. Such perceptions cannot be controlled and changed easily because they are held by individuals and/ or groups that are committed to it and consider it as an acceptable practice and phenomenon. However, the most critical cause of conflict is ethnicity. It has a direct relationship with perceptions. Wrong perceptions lead to stereotyping certain ethnic groups. The findings show that this is the main cause of conflict in AAU. Students need to study and work on group assignments and projects but prefer to work within their own ethnic groups. This attitude is the result of the emphasis of the present Ethiopian Education and Training Policy (1994) and the Higher Education Proclamation (2009) that emphasis ethnic background, language, religious and other diversity issues in higher educational institutions. Although the policies have attempted to implement a multicultural policy framework by designing courses like Civics and Ethical Education, they are found to be inadequate and weak in promoting a peaceful environment that tolerates diversity (Hailemariam, 2016: 305).

Main Conclusion 2. The study attempted to classify what the nature of conflict is in AAU. Theoretically, conflict can be classified as functional or dysfunctional. By and large, conflict resolution mechanisms mentioned by the participants do not include dialogue or tolerance. Conflict generally escalates into violence and destruction of property. The teaching-learning process is also affected. Hence, diversity management is ineffective. Conflicts that do not produce new ideas to reconstruct and make changes or improve the status quo are classified as dysfunctional conflict. The reality is that ethnicity leads to serious conflicts. For instance, the conflict where Oromo students were active participants, claiming their disagreement with the new master plan of Addis Ababa which was planned to integrate with the nearby Oromia towns was a high-level conflict. When students feel that any regional issue affects their ethnic group, they protest and the Federal Police are called in to intervene. In such cases, although the conflict seems dysfunctional, in the course of time, it can have bring about change in government policies. The Addis Ababa Integrated Master Plan was totally not implemented because it involved millions of Oromo protesters throughout the nation. Thus, if the political system of Ethiopia was not committed to lipservice democracy, student protests would be considered as a motivation to review the policy and make adjustments to address sensitive social and political issues. Failure to do so leads the students to engage in violence and they then have to suffer the consequences and pay sacrifices, such as serving time in jail. I thus conclude that it is the supra-system (the government) and the subsystem (AAU) that contributes to the dysfunctional conflict that prevails in AAU.

Main Conclusion 3. The other important question was to evaluate the effectiveness of measures taken by AAU to resolve conflict. According to the findings, AAU has formed a Peace Club and its formation and panels are also recognized by the Board of Directors. It conducts open panel discussions and invites students to participate in debates about tolerance of diversity and creating a peaceful environment. This is a positive and effective means of resolving and neutralizing dysfunctional conflict. However, the traditional, administrative measures still exist which do not create a peaceful environment but rather create a vicious cycle of conflict and impede the generation of new ideas, creating frustration, and hostility which have a negative impact on the mandate of a university such as AAU which is the pioneer in the Ethiopian higher education history. Thus, it can be concluded that AAU management is still not able to think strategically and in an innovative manner to resolve the ongoing conflict among students.

Main Conclusion 4. Finally, how peace education can 
be implemented in AAU was investigated. The courses that are delivered in AAU directly focus on the respective disciplines and the knowledge, skills and attitudes included in their related courses. However, there is no course that is offered that teaches about peace or tolerance of diversity. Hence, it can be concluded that the absence of such a course contributes to the failure to resolve the frequent conflicts in AAU.

\section{Recommendations}

In light of the conclusions, recommendations for policy and practice as well as further research are offered in this section.

\section{Policy and Practice}

Recommendation 1. The Ethiopian Education and Training Policy (1994) stated its commitment to address diverse education needs. This was supported by the Higher Education Proclamation no. $351 / 2003$ and Higher Education Proclamation no. 650/2009 (FDRE 2009: 49794981) of which Article 4(8), and Article 7(11) declare that the aim of Ethiopian higher education is to promote a "multicultural community life" and value "democracy and multiculturalism". However, in the context of AAU, it has not been possible to maintain peace or resolve conflict wisely. Hence, both the policy and proclamation focus on diversity management, creating the big picture of citizenship and unity based on peace and democratic thinking. Hence, the Education and Training Policy and Higher Education Proclamation should be done reviewed and amended, given the reality of the conflict that prevails in AAU and other higher education institutions. Moreover, students should be consulted in improving the policy and kept informed of progress.

Recommendation 2. The aims of the Education and Training Policy and the Higher Education Proclamation go some way to promoting diversity and its management. However, to support these aims, the AAU curriculum should offer Peace Education as a course and deliver it across the whole university. This will foster peace, democratic thinking and multiculturalism amongst students. Moreover, it will translate the policy and proclamation into practice. Its, implementation would have a positive impact on resolving conflict in AAU.

Recommendation 3. Peace education can take the form extracurricular activities. It can include expanding the peace club to all campuses as it is currently operating on the main campus only. It can arrange panel discussions, dramas, workshops, sport activities and the like to promote peace without formal arrangements. This could make peace education more acceptable and easily internalized to change the attitudes of the university community.

Recommendation 4. Once AAU seeks such strategic solutions, it would increase the capacity to resolve conflicts on its own. Thus, the intervention of security forces for conflicts would be a very rare necessity. It thus calls for the university administration to exercise all the powers vested in it by the Higher Education Proclamation and MoE. It is further proposed that university mandates should be reviewed to address gaps if any which impedes the mandates of the AAU observed practically or to get additional mandates and autonomy if there are restrictions or limitations

\section{Further Research}

Recommendation 1. In the Ethiopian context, diversity is an opportunity that allows for the generation of new ideas, collaboratively deals with problems and contributes to the value and effort of all to build a peaceful and stronger nation. On the other hand, if unprofessionally and unwisely treated, it is a curse and extremely difficult to manage because conflicts become dysfunctional. In order to create peaceful universities, further research can be conducted especially in areas that are not addressed by this research. Research is needed on how policies can be made more realistic and feasible, in addition to making them more acceptable.

Recommendation 2. The universities other than AAU face similar challenges, the absence of peaceful environment and the adversary effect of dysfunctional conflict. However, the magnitude of conflict may differ from one university to another for various reasons. It is thus also important to conduct comparative research in other universities and have a greater understanding of the issue and, in line with this, to evaluate the inclusion of peace education in the curriculum.

Recommendation 3. The findings of this study and the proposal of peace education can further serve as a baseline to propose peace education at lower grades (preparatory, high school and primary education). It could help to decide if peace education is a requisite in lower levels. Moreover, it is possible to decide on the content and delivery mode of peace education curriculum at the university level if decided to provide the program at lower levels.

\section{REFERENCES}

Abdulghani Muthanna \& Guoyuan Sang (2018). Conflict at higher education institutions: factors and solutions for Yemen. Journal of Comparative and International Education, 48:2, 206223. DOI: $10.1080 / 03057925.2017 .1298434$ (in English)

Adeyemi, T. \& Ademilu, S. (2012). Conflict Management Strategies and Administrative Effectiveness in Nigerian Universities. Journal of Emerging Trends in Educational Research and Policy Studies. 3 (3): 368-375. (in English)

Alquraan, M. F. (2014). A Cross-Cultural Study of Students' Perceptions of Assessment Practices in Higher Education. Education, Business and Society: Contemporary Middle Eastern. Issues 7 (4): 293-315. DOI: 10.1108/ebs-08-2014-0044 (in English)

Anstey, M. (2013). Practical Peace Making. Cape Town: Shumani Digital.

Khan, B. \& Bibi, Z. (2012). An inquiry into conflict management strategies: Study of higher education institutions of Khyber Pakhtunkhwa, Pakistan. Research Journal of Social Science and Management, (2) 5. Retrieved from https://files.eric.ed.gov/fulltext/ ED538331.pdf (in English)

Broni, A. (2012). Conflict management in Ghanaian Schools: A Case study of the role of leadership of Winneba Senior High School. International Journal of Educational Planning \& Administration, 2(2). Retrieved from https://www.ripublication.com/ ijepa/ijepav2n2_02.pdf (in English)

Chelule, E. (2014). Impediments to implementation of peace education in public universities in Kenya. IOSR Journal of Humanities and Social Science, 19(3). DOI: 10.9790/0837-1932174185 (in English)

Alimba, Chinyere, N. (2013). Peace education, transformation of higher education and youth empowerment for peace in Africa. International Journal of Scientific \& Technology Research, 2(12): 338-347. Retrieved from http://citeseerx.ist.psu.edu/viewdoc/ download?doi=10.1.1.432.6342\&rep=rep1\&type=pdf (in English)

Datzberger, S. (2017). Peacebuilding through non-formal education programmes: a case study from Karamoja, Uganda, International Peacekeeping, 24:2, 326-349. DOI: 10.1080/ 13533312.2016.1214073. (in English)

Demir, S. (2011). An overview of peace education in Turkey: Definitions, difficulties, and suggestions: A qualitative analysis. Educational Sciences: Theory \& Practice, (11) 4. Retrieved from https://files.eric.ed.gov/fulltext/EJ962672.pdf (in English) 
Di Manna, L. (2012). Exploring opportunities for conflict resolution in higher education. Unpublished doctoral thesis. Minneapolis: Walden University.

Etim, N \& Okey, S. (2013). Conflict management in the Nigerian university system. Journal of Educational and Social Research, 3 (8): 17-25. DOI: 10.5901/jesr.2013.v3n8p17. (in English)

Harris, M. (2004). Peace education theory. Journal of Peace Education, 1 (1): 5-20. DOI: 10.1080/1740020032000178276. (in English)

Koklu, M. (2012). Participations in decision-making, desires for participation, job satisfactions and conflict management styles of secondary education teachers. Journal of Education and Science, 37 (165): 1-16

Majola, V. (2013). The role of the school governing body (SGB) in conflict management: A case study. Unpublished master's dissertation. Pretoria: University of South Africa.

Miall, H. (2004). Conflict Transformation: A Multi-Dimensional Task. In: Austin A., Fischer M., Ropers N. (eds). Transforming Ethnopolitical Conflict. VS Verlag für Sozialwissenschaften, Wiesbaden. DOI: https://doi.org/10.1007/978-3-663-05642-3_4. (in English)

National Open University of Nigeria. (2009). Introduction to conflict resolution processes. Lagos: National Open University of Nigeria.

Nwafor, N. (2012). Peace education and national development: A critical appraisal. Journal of Economics and Sustainable Development, 3 (11). Retrieved from https://iiste.org/Journals/index.php/ JEDS/article/viewFile/3840/3894 (in English)

Oladitan, O. I., Ajibua, M. A., Fashogbon, B. A. \& Ajayi, M. O. (2014). Influence of leadership style on interpersonal conflict management among teaching and non-teaching staff in secondary schools in Osun State, Nigeria. Higher Education of Social Science, 6 (1): 39-44. DOI: 10.3968/j.hess. 1927024020140601. 2955. (in English)

Posigha, E \& Oghuvwu, V. (2009). Conflict among library staff in Bayelsa and delta State of Nigeria. International Journal of Labour and Organisational Psychology, 3(1\&2).

Sujatmiko, I. (2012). Conflict transformation and social reconciliation: The case of Aceh, Indonesia. Asian Social Science, 8 (2). DOI: 10.5539/ass.v8n2p104 (in English)

Rahim, A. (2010). Managing conflict in organizations. Westport: Greenwood. Retrieved from http://www.untag-smd.ac.id/ files/Perpustakaan_Digital_1/CONFLICT\%20MANAGEMENT\%20Managing\%20conflict\%20in\%20organizations.pdf (in English)

Robbins, S. and Judge, T. (2013). Essentials of organizational behavior. Upper Saddle River: Pearson Education. Retrieved from https://www. pearson.com/us/higher-education/product/ Robbins-Essentials-of-Organizational-Behavior-13th-Edition/ 9780133920819.html (in English)

Salomon, G. \& Cairns, E. (eds.) (2010). Handbook on peace education. New York: Psychology Press.

The Federal Democratic Republic of Ethiopia, House of Peoples' Representative. (1994). Constitution of the Federal Democratic Republic of Ethiopia. Addis Ababa: Birehanena Selam Printing Press.

Yonas, Adaye (2018). Peacebuilding through Peace Education in the Horn of Africa: A transformative cosmopolitan Perspective. In: Peacebuilding in Contemporary Africa. In Search of Alternative Strategies. Ed. by K. Omeje. Routledge, 226 p. (in English).

Van Vuuren, H. J., Van der Westhuizen, P. C., \& Van der Walt, J. L. (2012). Themanagement of diversity in schools: International Journal of Educational Development, 32(1), 155-162. DOI: 10.1016/j.ijedudev.2010.11.005 (in English)

Vaessen, B. Antoine van den Beemt, Gerard van de Watering, Ludo W. van Meeuwen, Lex Lemmens \& Perry den Brok (2017). Students' perception of frequent assessments and its relation to motivation and grades in a statistics course: a pilot study, Asses- sment \& Evaluation in Higher Education, 42: 6, 872-886. DOI: 10.1080/02602938.2016.1204532 (in English)

Watson, N., Watson, K., Stanley, C. (2017). Conflict Management and Dialogue in Higher Education A Global Perspective (2nd Edition). Texas A\&M University. Beverly Irby, Texas A\&M University.

Williams, F. (2011). Interpersonal conflict: The importance of clarifying manifest conflict behavior. International Journal of Business, Humanities \& Technology, 1 (3):148-160.

Mayer, B. (2012). The dynamics of conflict. San Francisco: Jossey-Bass.

Wintersteiner, W. (2013). Building a global community for a culture of peace: The Hague Appeal for Peace Global Campaign for Peace Education (1999-2006). Journal of Peace Education, 10 (2): 138-156. DOI: 10.1080/17400201.2013.790250 (in English)

\section{LIST OF REFERENCE LINKS}

Abdulghani Muthanna \& Guoyuan Sang. Conflict at higher education institutions: factors and solutions for Yemen. Journal of Comparative and International Education, 2018. 48:2, 206223. DOI: $10.1080 / 03057925.2017 .1298434$.

Adeyemi T. \& Ademilu S. Conflict Management Strategies and Administrative Effectiveness in Nigerian Universities. Journal of Emerging Trends in Educational Research and Policy Studies. 2012. 3 (3): 368-375.

Alquraan M. F. A Cross-Cultural Study of Students' Perceptions of Assessment Practices in Higher Education. Education, Business and Society: Contemporary Middle Eastern. 2014. Issues 7 (4): 293-315. DOI: 10.1108/ebs-08-2014-0044.

Anstey M. Practical Peace Making, Cape Town: Shumani Digital, 2013.

Khan B. \& Bibi Z. An inquiry into conflict management strategies: Study of higher education institutions of Khyber Pakhtunkhwa, Pakistan. Research Journal of Social Science and Management, 2012. (2) 5. Retrieved from https://files.eric.ed.gov/fulltext/ ED538331.pdf (дата звернення 19.06.2018).

Broni A. Conflict management in Ghanaian Schools: A Case study of the role of leadership of Winneba Senior High School. International Journal of Educational Planning \& Administration, 2012. 2(2). Retrieved from https://www.ripublication.com/ijepa/ ijepav2n2_02.pdf (дата звернення 11.09.2018).

Chelule E. Impediments to implementation of peace education in public universities in Kenya. Journal of Humanities and Social Science, 2014. 19(3). DOI: 10.9790/0837-1932174185

Alimba Chinyere N. Peace education, transformation of higher education and youth empowerment for peace in Africa. International Journal of Scientific \& Technology Research, 2013. 2(12): 338-347. Retrieved from http://citeseerx.ist.psu.edu/viewdoc/ download?doi=10.1.1.432.6342\&rep=rep1\&type=pdf (дата звернення 14.06.2018)

Datzberger S. Peacebuilding through non-formal education programmes: a case study from Karamoja, Uganda, International Peacekeeping, 2017. 24:2, 326-349. DOI: 10.1080/13533312.2016.1214073.

Demir S. An overview of peace education in Turkey: Definitions, difficulties, and suggestions: A qualitative analysis. Educational Sciences: Theory \& Practice, 2011. (11) 4. Retrieved from https://files.eric.ed.gov/fulltext/EJ962672.pdf (дата звернення 04.07.2018)

Di Manna L. Exploring opportunities for conflict resolution in higher education. Unpublished doctoral thesis. Minneapolis: Walden University, 2012.

Etim N \& Okey S. Conflict management in the Nigerian university system. Journal of Educational and Social Research, 2013. 3 (8): 17-25. DOI: 10.5901/jesr.2013.v3n8p17.

Harris M. Peace education theory. Journal of Peace Education, 2004. 1 (1): 5-20. DOI: 10.1080/1740020032000178276. 
Koklu M. Participations in decision-making, desires for participation, job satisfactions and conflict management styles of secondary education teachers. Journal of Education and Science, 2012. 37 (165): 1-16

Majola V. The role of the school governing body (SGB) in conflict management: A case study. Unpublished master's dissertation. Pretoria: University of South Africa, 2013.

Miall H. Conflict Transformation: A Multi-Dimensional Task. In: Transforming Ethnopolitical Conflict / Austin A., Fischer M., Ropers N. (eds). VS Verlag für Sozialwissenschaften, Wiesbaden, 2004. DOI: https://doi.org/10.1007/978-3-663-05642-3_4.

National Open University of Nigeria. Introduction to conflict resolution processes. Lagos: National Open University of Nigeria, 2009.

Nwafor N. Peace education and national development: A critical appraisal. Journal of Economics and Sustainable Development, 2012. 3 (11). Retrieved from https://iiste.org/Journals/index.php/ JEDS/article/viewFile/3840/3894 (дата звернення 12.08.2018).

Oladitan O. I., Ajibua M. A., Fashogbon B. A. \& Ajayi M. O. Influence of leadership style on interpersonal conflict management among teaching and non-teaching staff in secondary schools in Osun State, Nigeria. Higher Education of Social Science, 2014. 6 (1): 39-44. DOI: 10.3968/j.hess.1927024020140601.2955.

Posigha E \& Oghuwwu V. Conflict among library staff in Bayelsa and delta State of Nigeria. International Journal of Labour and Organisational Psychology, 2009. 3(1\&2).

Sujatmiko I. Conflict transformation and social reconciliation: The case of Aceh, Indonesia. Asian Social Science, 2012. 8 (2). DOI: $10.5539 / a s s . v 8 n 2 p 104$

Rahim A. Managing conflict in organizations. Westport: Greenwood, 2010. Retrieved from http://www.untag-smd.ac.id/files/ Perpustakaan Digital 1/CON-FLICT\%20MANAGEMENT\%20Managing $\% 20$ conflict $\% 20$ in $\% 20$ organizations.pdf (дата звернення 05.08.2018)

Robbins S. and Judge T. Essentials of organizational behavior.
Upper Saddle River: Pearson Education, 2013. Retrieved from https://www.pearson.-com/us/higher-education/product/RobbinsEssentials-of-Organizational-Behavior-13th-Edition/ 9780133920819.html (дата звернення 01.08.2018)

Handbook on peace education / Salomon G. \& Cairns E. (eds.). New York: Psychology Press, 2010.

The Federal Democratic Republic of Ethiopia, House of Peoples' Representative. Constitution of the Federal Democratic Republic of Ethiopia. Addis Ababa: Birehanena Selam Printing Press, 1994.

Yonas Adaye. Peacebuilding through Peace Education in the Horn of Africa: A transformative cosmopolitan Perspective. In: Peacebuilding in Contemporary Africa. In Search of Alternative Strategies / Ed. by K. Omeje. Routledge, 2018. 226 pp.

Van Vuuren H. J., Van der Westhuizen P. C. \& Van der Walt J. L. Themanagement of diversity in schools: International Journal of Educational Development, 2012. 32(1), 155-162. DOI: 10.1016/j.ijedudev.2010.11.005

Vaessen B. Antoine van den Beemt, Gerard van de Watering, Ludo W. van Meeuwen, Lex Lemmens \& Perry den Brok. Students' perception of frequent assessments and its relation to motivation and grades in a statistics course: a pilot study, Assessment \& Evaluation in Higher Education, 2017. 42: 6, 872-886. DOI: 10.1080/02602938.2016.1204532.

Watson N., Watson K., Stanley C. Conflict Management and Dialogue in Higher Education A Global Perspective (2nd Edition). Texas A\&M University. Beverly Irby, Texas A\&M University, 2017.

Williams F. Interpersonal conflict: The importance of clarifying manifest conflict behavior. International Journal of Business, Humanities \& Technology, 2011. 1 (3):148-160.

Mayer B. The dynamics of conflict. San Francisco: JosseyBass, 2012.

Wintersteiner W. Building a global community for a culture of peace: The Hague Appeal for Peace Global Campaign for Peace Education (1999-2006). Journal of Peace Education, 2013. 10 (2): 138-156 DOI: 10.1080/17400201.2013.790250.

Верета Йозеф Вубалем,

Університет громадянської служби Ефіопії,

Інститут лідерства та ефективного управління (Аддис-Абеба, Ефіопія)

e-mail: Yoseph.Woubalem@ecsu.edu.et, ORCID 0000-0002-6727-5637

\section{PЕАСЕ EDUCATION ДЛЯ УПРАВЛІННЯ ІНСТИТУЦІЙНИМИ КОНФЛІКТАМИ В УНІВЕРСИТЕТІ АДДИС-АБЕБИ}

Стаття присвячена усвідомленню суті соціальних конфліктів в освітньому середовищі та пошуку шляхів управління ними на прикладі. Відповідно до пануючих методологічних настанов, соціальний конфлікт, що правильно управляється, має для організації не лише негативні, але й позитивні наслідки. Автор звертається до конкретного сюжету - ситуації в Університеті Аддіс-Абеби (Ефіопія) - для узагальнення природи, причин, типології, потенційних наслідків конфліктів в університетах. Університет Аддіс-Абеби є піонером вищої освіти в Eфіопії, який був створений в 1950 році. Сьогодні в ньому навчається понад 48 тисяч студентів 3 усіх регіонів країни. Університет Аддіс-Абеби розглядається в статті як міні-модель Ефіопії: студентські громади і земляцтва репрезентують усі наявні етнічні, конфесійні, мовні, соціокультурні спільноти країни. Таке розмаїття час від часу призводить до соціального напруження в кампусах і навіть до відкритих конфліктів. Як метод запобігання конфліктів автор пропонує соціальну технологію Peace education, під якою розуміється культивування цінностей, розповсюдження знань, розвиток відносин, навичок і поведінки, спрямованих на досягнення миру і гармонії з собою, з іншими і з природним середовищем. У статті наводяться практичні поради і рекомендації щодо управління конфліктами в університетах.

Ключові слова: конфрлікт; управління конфрліктами; Peace education; універсuтет; Aддіс-Aбеба; Eфpioпія.

(C) Wereta Yoseph Woubalem

Надійшла до редакції: 21.11.2018

Прийнята до друку: 06.02.2019 